\title{
Prenatal diagnosis of 21 trisomy by quantification of methylated fetal DNA in maternal blood: study on 10 pregnancies
}

\section{Diagnosticul prenatal al trisomiei 21 prin cuantificarea ADN-ului fetal metilat din sângele matern: studiu pe 10 sarcini}

\author{
Eusebiu V. Gorduza ${ }^{1}$, Roxana Popescu ${ }^{1 *}$, Lavinia Caba ${ }^{1}$, Iuliu Ivanov ${ }^{2}$, \\ Violeta Martiniuc ${ }^{3}$, Florina Nedelea ${ }^{4}$, Mariela Militaru ${ }^{5}$, Demetra G. Socolov ${ }^{6}$ \\ 1. University of Medicine and Pharmacy "Grigore T. Popa" Iaşi, Department of Medical Genetics \\ 2. Regional Institute of Oncology Iaşi, Department of Molecular Biology \\ 3. "Cuza Vodă" Obstetrical and Gynaecology Hospital Iaşi, Department of Prenatal Diagnosis \\ 4. "Filantropia" Obstetrical and Gynaecology Hospital Bucharest, Department of Prenatal Diagnosis \\ 5. University of Medicine and Pharmacy "Iuliu Hațieganu" Cluj Napoca, Department of Medical Genetics \\ 6. University of Medicine and Pharmacy "Grigore T. Popa" Iaşi, Department of Obstetric and Gynaecology
}

\begin{abstract}
Background. The Down syndrome is a severe disease without pathogenic therapy. The only possibility to reduce the consequences of disease is prenatal screening and diagnosis. The gold standard in prenatal diagnosis is the conventional banding cytogenetic analysis of fetal cells obtained by invasive procedures. To reduce the complications, in the last years different methods to detect fetal cells or DNA in maternal blood were developed. Aim. The aim of study was to verify the reliability of quantification by immunoprecipitation of methylated fetal DNA in maternal blood in the prenatal diagnosis of 21 trisomy. Method. We analyzed probes from 12 pregnant women (7 with confirmed 21 trisomy pregnancy and 5 with normal pregnancy), with two being rejected for technical considerations. For each probe we carried out: extraction of total DNA (maternal and fetal), DNA fragmentation, immunoprecipitation of methylated DNA, washing, isolation of DNA and qPCR for immunoprecipitated DNA. To highlighting specific methylated regions on fetal 21 chromosome we used eight pairs of specific primers for chromosome 21. Finally we analysed the results of $q P C R$ applying the formula $D=-$ $6.331+0.959 X E P 4+1.188 X E P 5+0.424 X E P 6+0.621 X E P 7+0.028 X E P 8+0.387 X E P 10-0.683 X E P 11+$

$0.897 X E P 12$, where $X E P i=$ fraction value for each marker. Results. In all normal pregnancies the value of $D$ factor was negative concordant with absence of trisomy (100\% specificity). In 5 from 6 pregnancies with 21 trisomy the value of $D$ factor was positive, which indicated a high sensibility. However, to a precise estimation of this method is required a larger number of cases that allowing the obtaining of statistically validated results.
\end{abstract}

Keywords: non-invasive prenatal diagnosis of 21 trisomy, methylated fetal DNA, immunoprecipitation

*Corresponding author: Roxana Popescu, University of Medicine and Pharmacy “Grigore T. Popa” Iaşi, 16 Universităţii Str., 700115, Iaşi, Romania. Phone: +40-741-025592, E-mail: fyfy_05@yahoo.com 


\section{Rezumat}

Introducere. Sindromul Down este o boală gravă, lipsită de terapie patogenică. Singurele posibilități de reducere a consecințelor bolii le reprezintă screeningul şi diagnosticul prenatal. Standardul de aur în diagnosticul prenatal este analiza cromosomică a celulelor fetale obținute prin proceduri invazive. Pentru reducerea complicațiilor, în ultimii ani au fost dezvoltate diferite metode de detecție a celulelor sau ADN-ului fetal în sângele matern. Scop. Scopul studiului a fost verificarea aplicabilității metodei de cuantificare prin imunoprecipitare a ADN-ului fetal metilat din sângele matern în diagnosticul prenatal al trisomiei 21. Metodă. Am analizat probe de la 12 gravide (7 cu făt cu trisomie 21 şi 5 cu făt euploid confirmate citogenetic), două probe fiind eliminate din considerente tehnice. Pentru fiecare probă am efectuat: extracția ADN-ului total (matern şi fetal), fragmentarea ADN-ului, imunoprecipitarea ADN-ului metilat, spălarea, izolarea ADN-ului şi qPCR pentru ADN-ul imunoprecipitat. Pentru evidențierea regiunilor metilate specifice pe cromosomii 21 fetali am utilizat opt perechi de amorse specifice cromosomului 21. In final, am analizat rezultatele qPCR aplicând formula: $D=-6,331+0,959 X E P 4+1,188 X E P 5+0,424 X E P 6+0,621 X E P 7+0,028 X E P 8+0,387 X E P 10-0,683 X E P 11$ $+0,897 X E P 12$ unde XEPi= valoarea fracției pentru fiecare marker. Rezultate. In toate sarcinile normale, valoarea factorului $D$ a fost negativă concordant cu absența trisomiei (specificitate 100\%). In 5 din 6 sarcini cu trisomie 21 valoarea factorului $D$ a fost pozitivă, ceea ce indică o sensibilitate crescută. Totuşi, pentru estimarea precisă a metodei este necesară analiza mai multor cazuri, ceea ce ar permite obținerea de date valabile statistic.

Cuvinte cheie: diagnosticul prenatal noninvaziv al trisomiei 21, ADN fetal metilat, imunoprecipitare

Received: $16^{\text {th }}$ June 2013; Accepted: $31^{\text {st }}$ August 2013; Published: $13^{\text {th }}$ September 2013.

\section{Introduction}

Down syndrome (DS) is a public health problem both by high frequency - 1/700 - 1/800 live births - and by comorbidities and intellectual disability $(1,2)$. In the absence of pathogenic therapies, the need for performance prenatal prophylaxis of trisomy 21 is evident. Prevention of DS uses secondary prophylaxis requiring prenatal detection of the disease. Methods for screening and prenatal diagnostic (PD) have been developed for this purpose. The screening identifies high-risk pregnancies by noninvasive methods, using biochemical and ultrasound parameters. Combined test applied during the first trimester, assess nuchal translucency, free human chorionic gonadotropin (free $\beta$-hCG), pregnancy-associated plasma protein (PAPP-A) and maternal age. The quadruple test, applied in the second trimester of pregnancy, measures alpha-fetoprotein (AFP), unconjugated estradiol (UE3), the unbound fraction of $\beta$-hCG and inhibin A, all correlated with maternal age. Integrated test totalizes measurements at various stages of pregnancy linking nuchal translucency and PAPP-A with quadruple test markers in the second quarter (2). Prenatal diagnosis is based on genetic analysis of fetal cells obtained by invasive methods that generate risks for the pregnant woman and the fetus. The methods of obtaining fetal biological material for prenatal diagnosis are chorionic villus sampling (I trimester), amniocentesis and cordocentesis (II trimester of pregnancy). All the invasive methods to obtaining fetal cells could induce bleeding, miscarriage and fetal malformations $(3,4)$. However, classic prenatal chromosome analysis has the advantage of $100 \%$ accuracy, allowing the detection of chromosomal abnormalities in the resolution limit of optical microscopy. The major disadvantage is the long period of 10-14 days required to complete the cell culture (5).

The introduction of molecular cytogenetic tests reduced the time to achieve results within two days, but have the disadvantage of targeted detection of certain chromosomal regions. The FISH technique, based on the hybridization of a labeled fluorescent probe and a specific chro- 
mosome, is applicable for the routine prenatal detection of aneuploidies of chromosome 13, 18, 21, $\mathrm{X}$ and $\mathrm{Y}$. The method has a high specificity and sensitivity (near to 100\%), but is expensive, timeconsuming and cannot detect all chromosomal anomalies. QF-PCR and MLPA techniques will produce rapid results at low cost, but are characterized by low sensitivity and specificity $(5,6)$.

Starting from the prerequisites of necessity for a prenatal diagnosis fast, cheap, safe and less traumatic for the pregnant woman and the fetus, noninvasive prenatal diagnostic methods (NPD) based on isolation of fetal cells or detection of free fetal DNA in maternal circulation (7) were implemented lately.

The passage of fetal cells in maternal circulation during pregnancy is low, so there is about $1 \mathrm{fetal}$ cell/ml of maternal blood. Their frequency slightly increases in the third trimester of pregnancy and in certain disorders associating placental dysfunction (8). The concentration methods of fetal cells - magnetic cell sorting (MACS) and fluorescent activated cell sorting (FACS) - increase the number of fetal cells, but also produce the loss of a large number of cells $(7,9)$.

Different studies proved that free fetal DNA disappears rapidly after birth, the mean half-life being 16.3 minutes, which creates prerequisites to an improvement in eliminating false positive prenatal diagnosis of fetal cells generated from a previous pregnancy (10). The amount of free plasma DNA in adult women is about 10-100 ng, but during the pregnancy there is a significant increase due to bone turnover and cell apoptosis (11). Free fetal DNA in maternal blood can be detected after the $5^{\text {th }}$ week of amenorrhea, after which there is a steady increase during pregnancy to peak at the end of pregnancy, but not more than 3.4 to $6.2 \%$ of the total free circulating DNA (12). Increased concentration of fetal DNA was identified in different obstetrical conditions (preeclampsia, preterm delivery, fetal-maternal hemorrhage, polyhydramnios etc.) but also in trisomy 21 (13-17).
Cleavage of maternal DNA generated fragments longer than $201 \mathrm{bp}$. The fetal DNA is cleaved into short fragments, usually less than $193 \mathrm{bp}$ (18).

Quantitative changes in DNA associated with fetal aneuploidies can be identified by indirect methods aimed at determining the allelic fraction (placental messenger RNA analysis, the DNA methylation and methylation specific fraction of fetal DNA) and direct methods molecular quantification (digital PCR and massive parallel sequencing) (19). Analysis of free fetal messenger RNA targeting genes expressed exclusively fetal DNA as PLAC4 gene (located on chromosome 21) or maspin gene (located on chromosome 18) $(12,20)$.

Direct detection methods require expensive equipment and reagents, are laborious, require advanced statistical processing and have not been validated by extensive studies $(12,19)$. Digital PCR accurately quantify very small amounts of DNA and allows detection of trisomy 21 by counting the number of target sequences on chromosome 21 compared to similar loci on other chromosomes, but the utility of analysis is probed in presence of more than 10,000 DNA sequences (7). Massive parallel sequencing solves the problem of scarceness of fetal DNA in maternal circulation, but has a low sensitivity and requires statistical methods for data processing (21).

A new approach to NPD was conducted by Papageorgiou et al. (2009) and focused on identifying localized regions on chromosome 21 that are differentially methylated (DMR), hypermethylated in the placenta and hypomethylated in peripheral blood. In addition, the methylation status must be maintained the same throughout pregnancy (22). For this, the first step performed was physical separation of methylated and nonmethylated DNA, obtaining a methylated sample. For this sample was quantified the level of hypermethylation for several fetal/maternal differentially methylated regions and the result relates to a reference value representing hypermethylation in pregnancies with normal fetuses (23). 
Table 1. Characteristics of the patients included in the study group

\begin{tabular}{|c|c|c|c|}
\hline Sample & Gestational age & Motivation of performing prenatal diagnosis & Fetal status \\
\hline PN 1 & 16 weeks & DTP & $\mathrm{T} 21 *$ \\
\hline PN 2 & 18 weeks & DTP & $\mathrm{T} 21 *$ \\
\hline PN 3 & 16 weeks & DTP & $\mathrm{T} 21^{*}$ \\
\hline $\mathrm{PN} 4$ & 11 weeks & nuchal fold $>3 \mathrm{~mm}$ & $\mathrm{~T} 21^{*}$ \\
\hline PN 5 & 16 weeks & AMA, pathological fetal ultrasound & $\mathrm{T} 21 *$ \\
\hline PN 6 & 16 weeks & AMA, DTP, pathological fetal ultrasound & $\mathrm{T} 21 * *$ \\
\hline PN 7 & 17 weeks & pathological fetal ultrasound & $\mathrm{N}^{*}$ \\
\hline PN 8 & 19 weeks & AMA, TTP & $\mathrm{N}^{*}$ \\
\hline PN 9 & 16 weeks & AMA, DTP & $\mathrm{N}^{*}$ \\
\hline PN 10 & 16 weeks & DTP, pathological fetal ultrasound & $\mathrm{N}^{*}$ \\
\hline PN 11 & 16 weeks & AMA, pathological fetal ultrasound & $\mathrm{T} 21 *$ \\
\hline PN 12 & 19 weeks & severe oligohydramnios & $\mathrm{N}^{*}$ \\
\hline
\end{tabular}

DTP - pathological double test, AMA - advanced maternal age, TTP -pathological triple test; T21 -trisomy 21, $\mathrm{N}$-euploid fetus; * confirmed by FISH; ** confirmed by fetal chromosome analysis

\section{Material and method}

The study group consisted of 12 pregnant women investigated between January and November 2012 in the Central Laboratory of Immunology and Genetics of University of Medicine and Pharmacy "Grigore T. Popa" Iaşi. The prenatal diagnosis was made on grounds of: advanced maternal age, biochemical screening and / or ultrasound positive signs for 21 trisomy. All pregnant women agreed to participate in the study and signed an informed consent (approved by the Bioethics Commission of University of Medicine and Pharmacy "Grigore T. Popa" Iaşi) after providing genetic counseling, knowing the significance of prenatal diagnosis. In 7 cases we discovered a trisomy 21 confirmed by FISH or conventional chromosomal analysis (Table 1).

The method used for NPD was that established by Papageorgiou et al. (2011) (23).

Working protocol has 6 stages: extraction of total DNA (maternal and fetal), DNA fragmentation, immunoprecipitation of methylated DNA, washing, isolation of DNA and qPCR for DNA immunoprecipitated.

For each pregnant were collected on EDTA $2 \mathrm{ml}$ of peripheral blood and DNA extraction from whole blood has been done up to 6 hours after blood sampling, using a kit QIamp DNA Blood Mini Kit ${ }^{\circledR}$ (Qiagen;West Sussex, UK). Finally, the DNA was quantified, divided into samples, labeled and stored in the collection of DNA in compliance with the quality and quantity of DNA evidence, traceability, anonymity, and the ergonomics.

The genomic DNA was fragmented by sonication at $40 \mathrm{~Hz}$, using a sequence of 15 sonication and $15 \mathrm{~s}$ rest alternative for 10 minutes, using a MRC Scientific Instrument Ultrasonic Cleaner.

The DNA sample was diluted in GenDNA TE to reach $0.1 \mu \mathrm{g} / \mu \mathrm{l}$, to get a final volume of $300 \mu \mathrm{l}$ of DNA $(30 \mu \mathrm{g})$. Verification was done by migration in Agarose gel using a $50 \mathrm{bp}$ ladder. Because there was no complete fragmentation of all samples, the procedure was repeated, and finally we obtained DNA fragments with sizes of 150-500 bp.

Methylated fetal DNA extraction was done by using magnetic beads and 5-methylcytosine antibody extraction according to the protocol - MagMeDIP (Magnetic Methylated DNA Immunoprecipitation kit - Diagenode () ). For this purpose, the DNA from each fetus was divided into three samples: two used for immunoprecipitation (IP) and one considered as evi- 


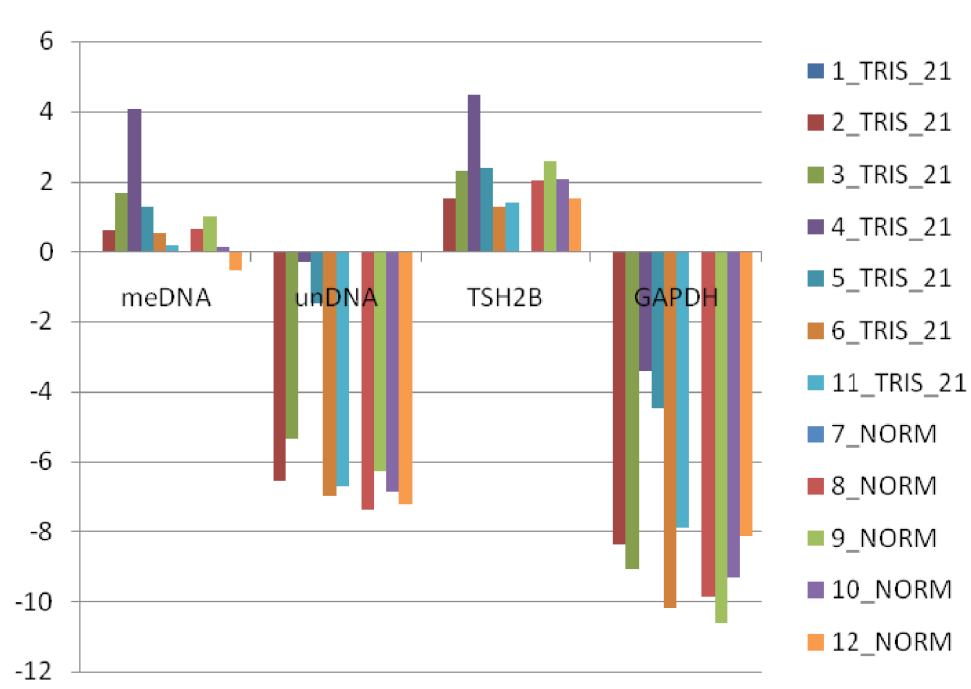

Figure 1. The results of analysis of imunoprecipitation efficiency by calculation of $\triangle \mathrm{CT}$ between IP and input for methylated DNA, unmethylated DNA, TSH2B (methylated human DNA), and GAPDH promoter (region of human unmethylated DNA)

dence input (input - IMP 10\% of the sample). Each IP contained $1 \mu \mathrm{g}$ of DNA. For immunoprecipitation was carried out a mixture of $75 \mu \mathrm{l}$ DNA, $5 \mu 1$ mixture of $20 \mu \mathrm{l}$ of diluted antibody of magnets $(100 \mu \mathrm{l}$ per reaction) which was stirred magnetically at $4^{\circ} \mathrm{C}$ for 12 hours.

Washing was carried out at cold, in magnetic stirrer in four successive stages (the first three using MagWash-1 buffer and the last using MagWash-2 buffer). At the end of washing, centrifugation was performed by keeping the sediment.

In the next step we isolated both immunoprecipitated DNA, as well as sample input.

To IP samples added $100 \mu$ l of buffer DIB with proteinase $K(1 \mu 1$ proteinase $K$ to $100 \mu$ l buffer DIB). To input sample added 92.5 $\mu 1$ buffer DIB to $7.5 \mu 1$ of DNA. The samples IP and input were incubated 15 minutes at $-55^{\circ} \mathrm{C}$, then another 15 minutes at $100^{\circ} \mathrm{C}$, followed by rapid stirring 5 minutes, centrifugation at $4^{\circ} \mathrm{C}$ with $14,000 \mathrm{rpm}$ and the supernatant was finally transferred to labeled tubes, stored at $-20^{\circ} \mathrm{C}$, representing prepared DNA for qPCR.

To achieve qPCR analysis of immunoprecipitated DNA we used a kit containing four pairs of specific primers validated for four types of DNA: methylated control DNA (primer pair 1) unmethylated control DNA (primer pair 2), human DNA methylated $(T S H 2 B)$ and human DNA unmethylated (GAPDH promoter). DNA from IP and input samples was diluted in $25 \mu 1$ solution containing each: $1 \mu \mathrm{l}$ of primer pair (Forward and Reverse) $12.5 \mu \mathrm{l} \mathrm{SYBR}$ Green PCR master mix, $5 \mu$ DNA sample and $6.5 \mu \mathrm{l}$ water.

Polymerase chain reaction (PCR) was carried out in the following sequence of steps: amplification at $95^{\circ} \mathrm{C}$ for 7 minutes (one cycle), amplification at $95^{\circ} \mathrm{C}$ for $15 \mathrm{~s}$ ( $40 \mathrm{cy}$ cles), amplification for 60 seconds at $60^{\circ} \mathrm{C}$ (40 cycles), and amplification at $95^{\circ} \mathrm{C}$ for $1 \mathrm{~min}$ (one cycle). After amplification was done 60 successive cycles of melting of 1 minute each, with gradual increase of temperature by $0.5^{\circ} \mathrm{C}$, the first cycle at $65^{\circ} \mathrm{C}$. The analysis of efficiency for immunoprecipitation was done by calculating the $\triangle \mathrm{CT}$ between IP and input for all four types of DNA: methylated DNA, unmethylated DNA, TSH $2 B$ and GAPDH promoter (Figure 1, Supplementary Table 1). Analysis of imunoprecipitation efficiency for a given locus was calculated using the following formula: $\%$ (meDNA-IP/ Total input $)=$

$2^{\wedge}((\mathrm{CT}(10 \%$ input $)-3.32)-\mathrm{CT}($ meDNA-IP $)) \mathrm{x} 100 \%$ where 2 is the AE (amplification efficiency), CT (meDNA-IP) and CT (10\% input) are threshold values obtained from exponential phase of qPCR for the methyl DNA sample and input sample respectively; the compensatory factor (3.32) is used to take into account the dilution 1:10 of the input.

To achieve qPCR for highlighting regions on chromosome 21 in the fetal methylated DNA were used eight pairs of specific primers chromosome 21, primers for hypermethylated region on chromosome 13 and hypomethylated region on chromosome 22 , according to the proto- 
Table 2. The values of $\Delta \mathrm{CT}$ for markers of chromosome 21

\begin{tabular}{|c|c|c|c|c|c|c|c|c|c|}
\hline \multirow{2}{*}{ Sample } & \multirow{2}{*}{ Pregnancy } & \multicolumn{8}{|c|}{$\Delta \mathrm{CT}$} \\
\hline & & EP4 & EP5 & EP6 & EP7 & EP8 & EP10 & EP11 & EP12 \\
\hline 1 & T21 & - & - & - & - & - & - & - & - \\
\hline 2 & $\mathrm{~T} 21$ & -2.7 & -3.2 & -7.1 & -7 & -5 & -4.3 & -7.6 & -7 \\
\hline 3 & $\mathrm{~T} 21$ & -2.8 & $2.7-$ & -8.7 & -8.3 & -4.1 & -5.1 & -7.5 & -7.1 \\
\hline 4 & $\mathrm{~T} 21$ & -1.8 & -2.1 & -7 & -3.1 & -3.6 & -2.2 & -6.7 & -5.4 \\
\hline 5 & $\mathrm{~T} 21$ & -3.5 & -3.7 & -7.9 & -7.5 & -4.6 & -4.6 & -8.8 & -5.4 \\
\hline 6 & $\mathrm{~T} 21$ & -4 & -4.1 & -9.8 & -7.3 & -4.5 & -5.1 & -7.8 & -7.4 \\
\hline 7 & $\mathrm{~N}$ & - & - & - & - & - & - & - & - \\
\hline 8 & $\mathrm{~N}$ & -4.6 & -4.7 & -9.1 & -5.2 & -5.2 & -3.6 & -7.6 & -6.4 \\
\hline 9 & $\mathrm{~N}$ & -4.3 & -4.1 & -8.5 & -6.2 & -4.7 & -4.1 & -8.2 & -6.1 \\
\hline 10 & $\mathrm{~N}$ & -5.2 & -4.7 & -8.1 & -3.5 & -7.3 & -5.4 & -7.7 & -7.3 \\
\hline 11 & $\mathrm{~T} 21$ & -3 & -2.5 & -9.3 & -7.8 & -7.1 & -5.8 & -7.7 & -7.9 \\
\hline 12 & $\mathrm{~N}$ & -4.5 & -4.2 & -8.4 & -5.1 & -6.5 & -5.1 & -4.9 & -6.5 \\
\hline
\end{tabular}

Table 3. The values of normalized $\Delta \mathrm{CT}$ and for median of normalized $\Delta \mathrm{CT}$ for markers of chromosome 21

\begin{tabular}{|c|c|c|c|c|c|c|c|c|c|}
\hline \multirow{2}{*}{ Sample } & \multirow{2}{*}{ Pregnancy } & \multicolumn{8}{|c|}{ Norm $\Delta \mathrm{CT}$} \\
\hline & & EP4 & EP5 & EP6 & EP7 & EP8 & EP10 & EP11 & EP12 \\
\hline 1 & $\mathrm{~T} 21$ & - & - & - & - & - & - & - & - \\
\hline 2 & $\mathrm{~T} 21$ & 0.15389 & 0.10881 & 0.00728 & 0.00781 & 0.03125 & 0.05076 & 0.00515 & 0.00781 \\
\hline 3 & $\mathrm{~T} 21$ & 0.14358 & 0.15389 & 0.00240 & 0.00317 & 0.05831 & 0.02915 & 0.00552 & 0.00728 \\
\hline 4 & $\mathrm{~T} 21$ & 0.287174 & 0.23325 & 0.00781 & 0.11662 & 0.08246 & 0.21763 & 0.00961 & 0.02368 \\
\hline 5 & $\mathrm{~T} 21$ & 0.08838 & 0.07694 & 0.00418 & 0.00552 & 0.04123 & 0.04123 & 0.00224 & 0.02368 \\
\hline 6 & $\mathrm{~T} 21$ & 0.0625 & 0.05831 & 0.00112 & 0.00634 & 0.04419 & 0.02915 & 0.00448 & 0.00592 \\
\hline 7 & $\mathrm{~N}$ & - & - & - & - & - & - & - & - \\
\hline 8 & $\mathrm{~N}$ & 0.04123 & 0.03847 & 0.00182 & 0.02720 & 0.02720 & 0.08246 & 0.00515 & 0.01184 \\
\hline 9 & $\mathrm{~N}$ & 0.05076 & 0.05831 & 0.00276 & 0.01360 & 0.03847 & 0.05831 & 0.00340 & 0.01457 \\
\hline 10 & $\mathrm{~N}$ & 0.02720 & 0.03847 & 0.00364 & 0.08838 & 0.00634 & 0.02368 & 0.00480 & 0.00634 \\
\hline 11 & $\mathrm{~T} 21$ & 0.125 & 0.17677 & 0.00158 & 0.00448 & 0.00728 & 0.01794 & 0.00592 & 0.00418 \\
\hline 12 & $\mathrm{~N}$ & 0.04419 & 0.0544 & 0.00296 & 0.02915 & 0.01104 & 0.02915 & 0.03349 & 0.01104 \\
\hline \multicolumn{10}{|c|}{ Median for normalized $\Delta \mathrm{CT}$} \\
\hline & & 0.042714 & 0.06464 & 0.00286 & 0.02818 & 0.01912 & 0.04373 & 0.00498 & 0.01144 \\
\hline
\end{tabular}

T21 - trisomy $21 ; \mathrm{N}$ - normal

col described by Papageorgiou et al in 2011 (23). Primers were reconstituted according to the standard protocol. For EP4 and EP6 primers was used a concentration of $900 \mathrm{nM}$, for EP5 primer was used a concentration of $450 \mathrm{nM}$, for EP7 primer was used at a concentration of $750 \mathrm{nM}$, while the other primer's concentrations were 300nM.
The reaction for PCR was carried out using a device PalmCyclerTM (Corbett, Lifesciences / Qiagen, Germantown, MD, USA) and the parameters of amplification were: pre-incubation $\left(95^{\circ} \mathrm{C} / 7 \mathrm{~min}\right)$, followed by 40 cycles of amplification $\left(95^{\circ} \mathrm{C} / 15 \mathrm{sec}\right.$ with ramp rate of $4.4 \% \mathrm{sec}$ and $60 \% 1 \mathrm{~min}$ with ramp rate $2.2 \% \mathrm{sec}$; fluorescent acquisition was done at 
Table 4. The values of the ratio for each sample, the median for normal sample and the median for trisomic sample for markers of chromosome 21

\begin{tabular}{|c|c|c|c|c|c|c|c|c|c|c|}
\hline \multirow{2}{*}{ Sample } & \multirow{2}{*}{ Pregnancy } & \multirow{2}{*}{$\mathrm{D}$} & \multicolumn{8}{|c|}{ Ratio } \\
\hline & & & EP4 & EP5 & EP6 & EP7 & EP8 & EP10 & EP11 & EP12 \\
\hline 1 & $\mathrm{~T} 21$ & & - & - & - & - & - & - & - & - \\
\hline 2 & $\mathrm{~T} 21$ & 1.56 & 3.60283 & 2.34314 & 2.54759 & 0.27722 & 1.63384 & 1.16073 & 1.03464 & 0.68261 \\
\hline 3 & $\mathrm{~T} 21$ & 1.41 & 3.36156 & 3.31370 & 0.84039 & 0.11258 & 3.04886 & 0.66666 & 1.10890 & 0.63689 \\
\hline 4 & $\mathrm{~T} 21$ & 12.4 & 6.72313 & 5.02264 & 2.73044 & 4.13857 & 4.31175 & 4.97617 & 1.93071 & 2.06928 \\
\hline 5 & $\mathrm{~T} 21$ & 0.34 & 2.06928 & 1.65685 & 1.46320 & 0.19602 & 2.15587 & 0.94280 & 0.45035 & 2.06928 \\
\hline 6 & $\mathrm{~T} 21$ & -2.96 & 1.46320 & 1.25566 & 0.39205 & 0.22517 & 2.31061 & 0.66666 & 0.90070 & 0.51732 \\
\hline 7 & $\mathrm{~N}$ & & - & - & - & - & - & - & - & - \\
\hline 8 & $\mathrm{~N}$ & -2.56 & 0.96535 & 0.82842 & 0.63689 & 0.96537 & 1.42234 & 1.88561 & 1.03464 & 1.03464 \\
\hline 9 & $\mathrm{~N}$ & -1.74 & 1.18849 & 1.25566 & 0.96535 & 0.48267 & 2.01150 & 1.33333 & 0.68261 & 1.27379 \\
\hline 10 & $\mathrm{~N}$ & -2.19 & 0.63689 & 0.82842 & 1.27379 & 3.13645 & 0.33177 & 0.54150 & 0.96535 & 0.55445 \\
\hline 11 & $\mathrm{~T} 21$ & 1.02 & 2.92641 & 3.80645 & 0.55445 & 0.15922 & 0.38110 & 0.41038 & 1.18849 & 0.36580 \\
\hline 12 & $\mathrm{~N}$ & -6.32 & 1.03464 & 1.17157 & 1.03464 & 1.03464 & 0.57765 & 0.66666 & 6.72313 & 0.96535 \\
\hline \multicolumn{11}{|c|}{ Median ratio normal } \\
\hline & & & 1 & 1 & 1 & 1 & 1 & 1 & 1 & 1 \\
\hline \multicolumn{11}{|c|}{ Median ratio trisomy 21} \\
\hline & & & 3.14399 & 2.82842 & 1.15179 & 0.21060 & 2.23324 & 0.80473 & 1.07177 & 0.65975 \\
\hline
\end{tabular}

T21 - trisomy $21 ; \mathrm{N}$ - normal

465-510), melting $\left(95^{\circ} \mathrm{C} / 15 \mathrm{sec}\right.$ with ramp rate $4.4 \% \mathrm{sec}, 65 \% \mathrm{~min}$ with ramp rate $1 \% \mathrm{sec}$, fluorescence acquisition was made at 465-510), cool $(40 \% 30 \mathrm{sec}$, ramp rate of $2.2 \% \mathrm{sec})$.

The amplification program used a temperature of $60^{\circ} \mathrm{C}$ for hybridization for all mixtures. In the mix of EP 4 at this temperature were obtained primer dimer thereby making it difficult to interpret. For mix EP4, application of a hybridization temperature of $64^{\circ} \mathrm{C}$ eliminated the nonspecific products, so for all mixes we got a single melting peak, which allowed the comparison samples. Samples 1 and 7 were not considered because was not obtained amplification for Input nor controls or for sets of primers used for the analysis of differentially methylated regions on chromosome 21 .

\section{Results}

For assessment of the results the following parameters were calculated: $\triangle \mathrm{CT}$ for normal and trisomic pregnancies, Normalized $\Delta \mathrm{CT}$ for normal and trisomic pregnancies, the ratio value per sample and ratio value per DMR, and the amount of discrimination D. For this we used the formulas:

$$
\begin{aligned}
& \Delta \mathbf{C T}^{\mathrm{PB} \text { Normal }}=\mathrm{CT}^{\mathrm{PB} \text { Normal IMP }}-\mathrm{CT}^{\mathrm{PB} \text { Normal IP }} \\
& \Delta \mathbf{C T}^{\mathrm{PB} \mathrm{T} 21}=\mathrm{CT}^{\mathrm{PB} \text { T21 IMP }}-\mathrm{CT}^{\mathrm{PB} \text { T21 IP }} .
\end{aligned}
$$

(where $\mathrm{PB}=$ Peripheral Blood, T21= Trisomy 21, IMP - Input; IP= Immunoprecipitated)

Norm $\Delta C T$ value ${ }^{\text {PB Normal }}=E^{\Delta C T P B \text { Normal }}$ (where Norm $=$ Normalized)

Norm $\Delta C T$ value $^{\mathrm{PB} \mathrm{T21}}=\mathrm{E}^{\Delta C T \mathrm{~PB} \mathrm{~T} 21}$, (where $\mathrm{E}=10^{(-1 / \mathrm{slope})}=$ efficiency of the primer)

Ratio Value $^{\text {Sample; DMR }}=$ Norm $\Delta \mathbf{C T}^{\mathrm{PB}}$ Sample (Normal or T21) / Median (Norm $\Delta \mathbf{C T}^{\mathrm{PB} \text { Normal) }}$

$$
D=-6,331+0,959 X_{\mathrm{EP} 4}+1,188 X_{\mathrm{EP} 5}+
$$

$0,424 X_{\mathrm{EP6}}+0,621 X_{\mathrm{EP} 7}+\mathbf{0 , 0 2 8} X_{\mathrm{EP8}}+\mathbf{0 , 3 8 7}$ $X_{\mathrm{EP} 10}-0,683 X_{\mathrm{EP} 11}+0,897 X_{\mathrm{EP} 12}$,

(where $X_{\mathrm{EP}}=$ fraction value for the 8 markers used: 4, 5, 6, 7, 8, 10, 11 şi 12 - Supplementary Table 1).

Applying the above formulas we obtained the results shown in Supplementary Tables 2, 3, and in Tables 2, 3, 4.

For better highlighting the results we achieved the Figure 2, which reflects the graphical 


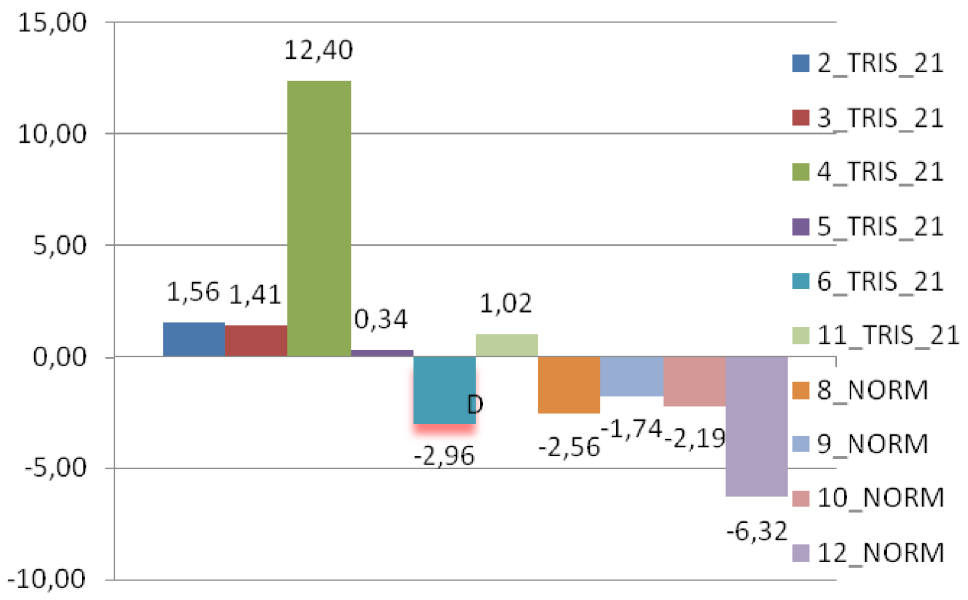

Figure 2. Graphical representation of the D-factor values for the 10 cases analysed

representation of value $\mathrm{D}$ for the 10 cases analyzed.

All pregnancies without trisomy 21 were correctly identified by obtaining a value of negative discrimination, the value of $\mathrm{D}$ ranging between -1.74 and -6.32 .

In five of the six samples with trisomy 21 considered in the final analysis, we discovered a correlation between the presence of trisomy and positive value of factor $\mathrm{D}$ : sample $2-\mathrm{D}=1.56$; sample $3-\mathrm{D}=1.41$; sample $4-\mathrm{D}=12.40$; sample $5-\mathrm{D}=0.34$, sample $11-\mathrm{D}=1.02$.

The only case in which we found negative values of factor $D$ was sample $6-D=-2.96$, which was inconsistent with the presence of trisomy.

\section{Discussions}

The results of our experiments confirmed the high specificity of this new method for testing the presence of 21 trisomy by a non-invasive diagnosis. Thus, we obtained a good correlation between the results of analysis of methylation of free fetal DNA from maternal blood and the results of prenatal diagnosis (by FISH method or by conventional karyotype). In all pregnancies with normal fetus, we obtained a negative value for discrimination factor $\mathrm{D}$, concordant with presence of 2 chromosome 21 . On the other hand, the anal- ysis of methylation of fetal DNA showed positive values for $\mathrm{D}$ factor in 5 from 6 probes from pregnancies with 21 trisomy. These results are concordant with an excess of hypermethylated fetal DNA, characteristic to aneuploidy.

Our study indicated that analysis of methylation status of fetal DNA from maternal blood could have a practical value, allowing a good discrimination between a normal pregnancy and a pregnancy with 21 trisomy's foetus. These data are concordant with studies of Papageorgiou et al. (23, 24). Although our study considered only ten probes - six from pregnancies with 21 trisomy and four from normal pregnancies - we found two positive aspects. First of all, in normal pregnancies the values of $\mathrm{D}$ factor were negatives (concordant with absence of an excess of hypermethylated fetal DNA) and this indicates the absence of false positive results with a $100 \%$ specificity. The second aspect was the good detection of 21 trisomy - five from six cases of pregnancies with 21 trisomy were confirmed by analysis of methylation status of fetal DNA. Thus, although the group is not statistically significant, we can say that the sensitivity of the method is quite high, correlated with the presence of a single false negative result. The presence of a sensibility less than $100 \%$ was observed also by Tong et al, that indicated a negative value of $\mathrm{D}$ factor in two of three cases of 21 trisomy analysed by same method (25).

The main aim of our study was to verify the reliability of quantification by immunoprecipitation of methylated fetal DNA in maternal blood in prenatal diagnosis of 21 trisomy and we had some limitations correlated with type of sampling collection. Thus, we perform the noninvasive prenatal test on blood samples providing from women with knowing fetal chromosomal formula: 7 with trisomy 21 and 5 with nor- 
mal fetus. The cohort is very small and the obtaining values for sensibility and sensitivity of method may differ for real values. Thus, it is impossible to estimate a positive or negative predictive value of the test, but such a problem was identified in any type of method for detection of fetal DNA in maternal blood (26-28).

In light of the above findings, it is clear that the validation of the method required several conditions. The first condition was to apply the method on a larger number of unselected cases, allowing the obtaining of statistically validated results. In addition, by finding a correction factor could smoothing the positive and the negative results, which enables a better discrimination between the two type of probes, with increasing the sensitivity and specificity of the method near $100 \%$.

\section{Conclusions}

Our study confirmed the reliability of noninvasive prenatal diagnostic method based on the comparison of the methylation status of maternal versus fetal DNA, which could be a future alternative to current invasive prenatal diagnostic methods marked by various incidents, the most serious being miscarriage.

\section{Acknowledgements}

This study was financially supported by the University of Medicine and Pharmacy "Grigore T. Popa" Iaşi, by internal grant - no. 28210/16.12.2011 - titled "Quantification of methylated fetal DNA - a new approach to noninvasive prenatal diagnosis of trisomy 21 ". The authors thank to the obstetricians of "CuzaVodă" Obstetrical and Gynaecology Iaşi for their help in obtaining the biological samples of amniotic fluid.

\section{Abbreviations}

$\mathrm{AE}=$ amplification efficiency

AFP = Alpha-fetoprotein

AMA $=$ advanced maternal age $\mathrm{bp}=$ base pairs

$\mathrm{CT}=$ cycle threshold

DMR $=$ Differentially methylated regions

DS = Down syndrome

DTP $=$ patological double test

FACS = Fluorescent activated cell sorting

FISH $=$ Fluorescence in situ hybridization

free $\beta$-hCG $=$ Free human chorionic gonadotropin

GAPDH-glyceraldehide3-phosphate dehydrogenase

IMP = Input;

IP = Immunoprecipitated

MACS = Magnetic cell sorting

MLPA = Multiplex ligation-dependent probe amplification

NPD = Noninvasive prenatal diagnostic

PAPP-A = Pregnancy-associated plasma protein

$\mathrm{PB}=$ Peripheral blood,

$\mathrm{PCR}=$ Polymerase chain reaction

$\mathrm{PD}=$ Prenatal diagnostic

PLAC4-placenta specific 4 gene

QF-PCR = Quantitative-fluorescent polymerase chain reaction

$\mathrm{q}-\mathrm{PCR}=$ Quantitative real time polymerase chain reaction

T21 = Trisomy 21,

TSH2B-testis-specific H2B histone gene

TTP $=$ patological triple test

UE3 = Unconjugated estradiol

$X_{\mathrm{EP}}=$ fraction value for each marker

\section{Supplementary data}

Supplementary Tables 1, 2, and 3 are available in the electronic version of the paper, published on the journal's website: www.rrml.ro.

\section{References}

1. Gorduza EV, Covic M, Stoica O, Voloşciuc M, Angheloni T, Butnariu L, et al. Studii clinice, epidemiologice şi citogenetice pe un lot de 221 pacienți cu sindrom Down. Rev Med Chir Soc Med Nat Iasi. 2007 AprJun;111(2):363-72.

2. Popovici C, Ştefănescu D, Mixitch F, Gug C, Covic M. Profilaxia bolilor genetice. Covic M, Ştefănescu D, Sandovici I (Eds.), Genetică Medicală, 2nd Ed. Polirom Iaşi, 2011:619-646

3. Gekas J, van den Berg DG, Durand A, Vallée M, Wildschut HI, Bujold E, et al. Rapid testing versus karyotyping in Down's syndrome screening: cost-effectiveness and detection of clinically significant chromosome abnor- 
malities. Eur J Hum Genet. 2011 Jan;19(1):3-9. 4. Tabor A, Alfirevic Z. Update on procedure-related risks for prenatal diagnosis techniques. Fetal Diagn Ther. 2010;27(1):1-7

5. Faas BH, Cirigliano V, Bui TH. Rapid methods for targeted prenatal diagnosis of common chromosome aneuploidies. Semin Fetal Neonatal Med. 2011 Apr;16(2):81-7.

6. Gorduza EV, Onofriescu M, Martiniuc V, Grigore M, Mihălceanu E, Iliev G. Importanța tehnicii FISH în diagnosticul prenatal al aneuploidiilor. Rev Med Chir Soc Med Nat Iasi. 2007 Oct-Dec;111(4):990-996

7. Hahn S, Yan Zhong X, Holzgreve W. Recent progress in non-invasive prenatal diagnosis. Semin Fetal Neonatal Med. 2008 Apr;13(2):57-62.

8. Bianchi DW, Williams JM, Sullivan LM, Hanson FW, Klinger KW, Shuber AP. PCR quantitation of fetal cells in maternal blood in normal and aneuploid pregnancies. Am J Hum Genet. 1997 Oct;61(4):822-9.

9. Bianchi DW, Simpson JL, Jackson LG, Elias S, Holzgreve W, Evans MI, et al. Fetal gender and aneuploidy detection using fetal cells in maternal blood: analysis of NIFTY I data. National Institute of Child Health and Development Fetal Cell Isolation Study. Prenat Diagn. 2002 Jul;22(7):609-15.

10. Swarup V, Rajeswari MR. Circulating (cell-free) nucleic acids--a promising, non-invasive tool for early detection of several human diseases. FEBS Lett. 2007 Mar;581(5):795-9.

11. Bischoff FZ, Lewis DE, Simpson JL. Cell-free fetal DNA in maternal blood: kinetics, source and structure. Hum Reprod Update. 2005 Jan-Feb;11(1):59-67.

12. Dennis Lo YM, Chiu RW. Prenatal diagnosis: progress through plasma nucleic acids. Nat Rev Genet. 2007 Jan;8(1):71-7.

13. Lo YM, Leung TN, Tein MS, Sargent IL, Zhang J, Lau TK, et al. Quantitative abnormalities of fetal DNA in maternal serum in preeclampsia. Clin Chem. 1999 Feb;45(2):184-8.

14. Leung TN, Zhang J, Lau TK, Hjelm NM, Lo YM. Maternal plasma fetal DNA as a marker for preterm labour. Lancet. 1998 Dec;352(9144):1904-5.

15. Lau TK, Lo KW, Chan LY, Leung TY and Lo YM. Cell-free fetal deoxyribonucleic acid in maternal circulation as a marker of fetalmaternal hemorrhage in patients undergoing external cephalic version near term. Am J Obstet Gynecol. 2000 Sep; 183(3):712-716.

16. Zhong XY, Holzgreve W, Li JC, Aydinli K, Hahn S. High levels of fetal erythroblasts and fetal extracellular DNA in the peripheral blood of a pregnant woman with id- iopathic polyhydramnios: case report. Prenat Diagn. 2000 Oct;20(10):838-41.

17. Zhong XY, Bürk MR, Troeger C, Jackson LR, Holzgreve W, Hahn S. Fetal DNA in maternal plasma is elevated in pregnancies with aneuploid fetuses. Prenat Diagn. 2000 Oct;20(10):795-8.

18. Chan KC, Zhang J, Hui AB, Wong N, Lau TK, Leung TN, et al. Size distributions of maternal and fetal DNA in maternal plasma. Clin Chem. 2004 Jan;50(1):8892.

19. van Lith JM, Benacerraf BR, Yagel S. Current controversies in prenatal diagnosis 2: Down syndrome screening: is ultrasound better than cell-free nucleic acids in maternal blood? Prenat Diagn. 2011 Mar;31(3):231-4.

20. Chim SS, Tong YK, Chiu RW, Lau TK, Leung TN, Chan LY, et al. Detection of the placental epigenetic signature of the maspin gene in maternal plasma. Proc Natl Acad Sci U S A. 2005 Oct;102(41):14753-8.

21. Fan HC, Quake SR. Sensitivity of noninvasive prenatal detection of fetal aneuploidy from maternal plasma using shotgun sequencing is limited only by counting statistics. PLoS One. 2010 May;5(5):e10439.

22. Papageorgiou EA, Fiegler H, Rakyan V, Beck S, Hulten M, Lamnissou K, et al. Sites of differential DNA methylation between placenta and peripheral blood: molecular markers for noninvasive prenatal diagnosis of aneuploidies. Am J Pathol. 2009 May;174(5):1609-18.

23. Papageorgiou EA, Karagrigoriou A, Tsaliki E, Velissariou V, Carter NP, Patsalis PC. Fetal-specific DNA methylation ratio permits noninvasive prenatal diagnosis of trisomy 21. Nat Med. 2011 Apr;17(4):510-3.

24. Papageorgiou EA, Patsalis PC. Non-invasive prenatal diagnosis of aneuploidies: new technologies and clinical applications. Genome Med. 2012 May;4(5):46.

25. Tong YK, Chiu RW, Chan KC, Leung TY, Lo YM. Technical concerns about immunoprecipitation of methylated fetal DNA for noninvasive trisomy 21 diagnosis. Nat Med. 2012 Sep;18(9):1327-8.

26. Norton ME, Rose NC, Benn P., Noninvasive prenatal testing for fetal aneuploidy: Clinical assessment and a plea for restraint, Obstet. Gynecol., 2013 April; 121(4): 847850

27. Nicolaides KH, Syngelaki A, Ashoor G, Birdir C., Touzet G. Noninvasive prenatal testing for fetal trisomies in a routinely screened first-trimester population. Am J Obstet Gynecol 2012;207:374.e1-6

28. Morain S, Greene MF, Mello MM., A New Era in Noninvasive Prenatal Testing, N Engl J Med. 2013 Jul 17, 1-4 DOI: 10.1056/NEJMp1304843. 